\title{
FinTech's business model in Mexico, a preliminary analysis
}

\author{
Luz del Carmen Díaz-Peña ${ }^{1}$ - Think Tank Financiero, México \& Instituto Tecnológico y de \\ Estudios Superiores de Monterrey, México
}

This study analyzes the key success variables in a fintech's business model. The data was obtained by a questionnaire applied to fifteen Mexican fintech's. Preliminary results show that the key success variables, according to a significant correlation with the firm's growth, are: an efficient use of infrastructure, customeroriented services, competitive wages and security of information; the more common type of fintech operation is the "payments and mobile money services" followed by "crowdfunding" and "investments". In Mexico, there is not a formal source that makes easier the knowledge of the industry, so the originality of the study lies on the contribution to a better introductory understanding of how fintech's operate, including other dimensions like the social and environmental ones which had not been considering before. Its limitation is the number of questioned firms, but future complementary studies could be done. It can be concluded that the technological dimension is the most relevant for the industry.

JEL Classification: M10, M13, M15, G00, G21, G23.

Keywords: Fintech, success variables, business model, financial inclusion, Mexico.

\section{El modelo de negocio de las Fintech en México, un análisis preliminar}

Este estudio analiza las principales variables de éxito en el modelo de negocio de una Fintech. Los datos fueron obtenidos mediante un cuestionario aplicado a quince Fintech mexicanas. Los resultados preliminares muestran que las variables clave de éxito, de acuerdo con una correlación significativa con el crecimiento de la empresa, son: un uso eficiente de la infraestructura, servicios orientados al cliente, salarios competitivos y la seguridad de la información; el tipo de Fintech más común es el de "pagos y servicios de dinero móvil" seguido de "crowdfunding" e "inversiones". En México, no existe una fuente formal que facilite el conocimiento de la industria, por lo que la originalidad de este estudio radica en la contribución a una mejor comprensión introductoria de cómo funcionan las Fintech, incluyendo otras dimensiones como las sociales y ambientales que no se habían considerando antes. Su limitante es el número de empresas interrogadas, pero se podrían hacer futuros estudios complementarios. Se puede concluir que la dimensión tecnológica es la más relevante para la industria.

Clasificación JEL: M10, M13, M15, G00, G21, G23.

Palabras clave: Fintech, variables de éxito, modelo de negocio, inclusión financiera, México.

\footnotetext{
${ }^{1}$ Corresponding author. Avenida Atlixcayotl No. 5781, C.P. 72453. Puebla México. Teléfono oficina:2223032000. Teléfono celular: 2211461696. E-mail: luzdiazp@tec.mx

* No source of funding for research development
} 


\section{Introduction}

Financial institutions are crucial to improve financial inclusion for all sectors of the economy and constantly the organizations are more interested in the financial local needs of the population in order to offer them the best products and services. In high-income economies 94 percent of adults have an account but in developing economies only 63 percent do (Demirguc-Kunt et al., 2018).

The fourth industrial revolution, remarkable by the artificial intelligence, internet of things and robotics, expanded to financial technology as a model based on financial services provided through critical technological innovations (Shin \& Choi, 2019). Digital platforms, cloud computing and marketplaces are examples of technological advances that have led new business models which satisfy consumers' financial needs through a different structure: online communication, reduced transaction costs and new regulations (Fernández De Lis \& Ortún, 2018).

"Mexico is attractive to investors seeking to develop the Fintech industry by three factors: the first, derived from the fact that half of the population lacks access to financial services resulting; the second relates to the regulatory framework which provides certainty and confidence for the attraction of investment and finally, the recovery of the Information and Communications Technology (ICT) market and the growing participation of providers of cloud services" (Bancomext, 2018a).

Experts expect that Mexican fintech ecosystem will continue to grow; a study from 2017 revealed that new companies could take over 30 percent of traditional banking market in Mexico within the next 10 years (Zbinden \& Kondova, 2019).

Despite the COVID-19 pandemic, the financial technology sector is changing; the FinTech's are now seeking to team more with emerging technology companies to gain access to new markets and products or to join with large financial institutions. The rise of Fintech, changing consumer behavior, and advanced technologies are disrupting the insurance industry (Deloitte, 2020).

The main objective of this research is to identify, as a preliminary analysis, the key success variables in a fintech's business model divided in six dimensions related to a sustainability framework of the Sustainability Accounting Standards Board (Materiality Map - SASB, 2021). In Mexico, there is not a formal data base for the industry that makes easier the analysis, so this study is innovative and different because it is an introductory understanding to become a reference and it includes new dimensions, the social and environmental, as embodied in the UN Sustainable Development Goals (Arner et al., 2020).

\section{Literature review}

\subsection{Global relevance of the fintech industry}

For Bancomext (2018), FinTech's are companies whose business models are using technology as the main enabler of its offer of financial products and services. This industry is characterized by collaborative and agile frameworks for solutions developments and different from the traditional financial products (Bancomext, 2018a). 
These companies are using technology to compete with the traditional banking processing, offering new products, better use experiences, and high level of personalization. Fintech is the new form of financial technique that stands on the basis of Information Technology (IT). "Criteria to categorize fintech business models are largely divided into four parts: banking and data analytics, payment, capital market technology and finance management including mobile payment, wire transfer, personal asset management and crowdfunding" (Quesada, 2017).

In the past few years, digital credit has emerged as an alternative mechanism for providing short-term loans. In a typical digital credit offering, a mobile phone operator will partner with a financial institution to provide loans directly to customers over an existing mobile money ecosystem (Francis et al., 2017). Recently, not only simple payment or wire transfer services but also algorithm techniques to accurately grasp with big-data analysis appear to personal asset management services (Park et al., 2015).

Several fintech companies provide intermediary credit-scoring services, aggregating customer data and applying machine learning algorithms to convert the data into credit scores, which are then provided to banks and other loan originators (Francis et al., 2017).

In order to analyze the different technologies that are changing the spectrum of financial services, Quezada (2017) divides it into four large areas according to the function that they can be used for:

1) Infrastructure: it refers to the system and resources that facilitate financial operations. Here are included the blockchain, digital identity, cybersecurity and privacy.

2) Money and payments: the need for carrying physical money is disappearing, and people even more make their payments in a digital manner. The nature of trade is changing and a new form of making the lend-borrow process is by peer-to-peer transfers (P2P).

3) Markets: nowadays there are prediction and speculative markets that enable users to bet on the probability of a future event, and the market price is directly linked to the likelihood that the event happened.

4) Platforms: there are numerous platforms emerging for the exchange of products and services that allow users to complete transactions without the involvement of a third party. Crowdfunding and sharing economy are examples of these.

Global Fintech revenues in 2018 were about $€ 92$ billion; the Fintech markets in the APAC and Americas regions are currently the largest, with both having around $40 \%$ of the global market share and the EMEA region is significantly smaller (with around 20\%). Also, the digital payments market is the largest segment within the fintech spectrum and accounts for more than $80 \%$ of global Fintech revenues (Deloitte, 2020).

The countries with a more mature fintech industry are USA, UK, Singapore, Lithuania, Switzerland, Netherlands and other developed countries (Findexable, 2019). For 2020, Findexable launched "The Global Fintech Index City Ranking Report", which evaluates more than 230 cities and 65 countries, it is designed to highlight opportunities and drive transparency across the ecosystem". The San Francisco Bay Area, London, New York, Singapore City and Sao Paulo round out the top (Findexable, 2019). 


\subsection{Fintech in emerging markets}

According to the Global Findex Database (2017) there are some interesting statistics for these countries (Bancomext, 2018a):

- Globally, 52\% of adults have sent or received digital payments in 2016, up from $42 \%$ in 2014 . Payments made through their technology platforms are facilitating higher account use in major emerging economies such as China, where $57 \%$ of account owners are using mobile phones or the internet to make purchases or pay bills.

- A study in Kenya found that access to mobile money services delivered big benefits, especially for women. It enabled women-headed households to increase their savings by more than a fifth; allowed 185000 women to leave farming and develop business or retail activities.

- Globally, 29\% of adults used the internet for one of these two purposes in the past year.

- The "fintech unicorn" are startups that reach more than 1000 million USD value, China has 10 of the 26 fintech unicorn in the world.

- About half of adults worldwide reported saving money in the past year. In high-income economies $71 \%$ reported saving, while in developing economies $43 \%$ did.

- In developing economies only $16 \%$ of adults reported saving for old age.

- In India and Mexico more than 50\% of the unbanked have a mobile phone; in China 82 percent do.

- Sub-Saharan Africa is the only region where the share of adults with a mobile money account exceeds 10\%. In 2014, East Africa was the region's mobile money hub. The share of adults with a mobile money account has now surpassed 30\% in Côte d'Ivoire and Senegal and 40\% in Gabon.

- In Latin America; Brazil, Mexico and Argentina lead the fintech sector, with 2 278, 1284 and 463 million USD of Gross Domestic Product (GDP) respectively.

Recent evidence shows that mobile phone usage can be used to predict loan default as well as digital credit can both reduce the cost of serving existing markets, and make it profitable to serve consumers outside the current financial system (Bjorkegren \& Grissen, 2018).

\subsection{Fintech in Mexico and its regulation}

According to Finnovista (2020), Mexico had a 46\% growth since 2019 and became the "boom" of Insurtech startups in 2020 with a mortality rate of only $4.5 \%$ of enterprises (Fintech Radar Mexico, 2020). Segments of payments and remittances, in conjunction with loans are those containing more startups; $82 \%$ of these are concentrated in the city of Mexico, Guadalajara, Monterrey, Mérida and Puebla (Bancomext, 2018b).

The Finnsummit is the most collaborative event in Latin America (held in Mexico City, Miami, and Bogota) in the innovation of the financial and insurance sectors and it seeks to search, create and 
implement new opportunities to transform the industry for financial institutions, insurance companies, investors, VCs, and startups (Fintech Radar Mexico, 2020).

The government's role in a fintech's ecosystem is essential and there are three central concepts to attend: 1) compromise, 2) innovation and 3) training (Bancomext, 2018b). With an appropriate intervention of the regulators, it can be reduced the systemic risk and assure the compliance of the law, what encourages a transparent and open government.

In Mexico, the Fintech Law was published on March 9, 2018 and entered into force in September 2018. The law considers three type of institutions: 1) Institutions of electronic payment funds and 2) collective financing institutions (crowdfunding) and cryptocurrencies (these types being referred to in the law as virtual assets). These institutions will be authorized, regulated and supervised by the Department of Finance (SHCP for its name in Spanish), ${ }^{2}$ the Bank of Mexico and the National Banking and Securities Commission (CNBV for its name in Spanish) 3 (Ley Para Regular Las Instituciones de Tecnología Financiera, 2018).

The Fintech Mexican Law seeks to give dynamism and accessibility to more users in the financial sector. The legislation is based on the principles of inclusion and financial innovation, protection to the consumer, preserving financial stability, promotion of healthy competition and prevention of money laundering and of the financing of terrorism (Ley Para Regular Las Instituciones de Tecnología Financiera, 2018).

Mexico advances in the modernization of the financial system; it is the 7th place worldwide in the regulation of the Fintech sector (Secretaría de Hacienda y Crédito Público, 2018).

\subsection{Fintech's business model and value creation}

Disruptive business models are developed around a novel technology and a customer-centric perspective (Roeder et al., 2018). Different technological mechanisms for competing are emerging with new strategies for value creation and the fintech sector is not the exception; the application and synthesis of technological capabilities are reducing barriers to entry and allow newcomers to insert themselves into the value chains (Gozman et al., 2018). So, new business models have been developed. "However, the scientific literature has not yet agreed on a universal definition of the term fintech due to the varying business strategy alignments, product and service portfolios, and digitallyinduced business models framing the concept" (Roeder et al., 2018).

Quesada (2017) suggests three important rules for banks that can be adopted for any fintech business model:

1) Personalized anything that can be personalized.

2) Have a faster rate of delivery of the product or service.

3) The information and transactions must have a transparent, unfriendly and unpredictable atmosphere.

\footnotetext{
${ }^{2}$ Secretaría de Hacienda y Crédito Público.

${ }^{3}$ Comisión Nacional Bancaria y de Valores.
} 
Eickhoff et al. (2017) develop a taxonomy of fintech business models suggesting six dimensions: 1) dominant technology component, 2) value proposition, 3) delivery channel, 4) customers, 5) revenue stream and 6) product/service offering (Eickhoff et al., 2017)

Another studies, show different relevant managerial challenges for the Fintech's. Lee\&Shin (2018) defined six variables: investment management, customer management, regulation, technology integration, security and privacy, and risk management (Lee \& Shin, 2018). On the other hand, Hills and Laforge (1992) say that new firms have more success when they access a sector that is in its early stage, so entry in a mature sector or markets, would only possible if the segment is not well provided by the leaders (Hills \& Laforge, 1992).

Arouche y Balaj (2020) examined some Swedish fintech companies' business models in order to identify what key factors could be found within the FinTech industry and they found four factors: 1) technological innovations, 2) digitization, 3) value proposition and 4) human resources (Arouche \& Balaj, 2020). Hence, the business model concept constitutes a major instrument to generate important knowledge for the variables identification that are crucial for the success of the FinTech ventures (Roeder et al., 2018).

Fintech innovation has the ability to shake up the entire financial landscape in the coming years; collaboration between banks and companies will prevail: the Fintech's can benefit from the financial institution's expertise in modeling and analysis, while the financial institution can gain insight into client's necessities, cost structure and revenue streams (Lee \& Shin, 2018).

\section{Methodology}

The methodology used is of qualitative and quantitative nature. The main stages to gather the information were: 1) literature review; 2) questionnaire design (appendix A); 3) survey application and 4) information analysis. To obtain information from the fintech firms, a questionnaire was electronically sent to the CEO of each company. The questionnaire was designed to obtain information about the firms in six different dimensions which are depicted in table 1, and they encompass different aspects where the firm could have strengths in order to succeed (Appendix B).

Table 1. Dimensions of questionnaire

\begin{tabular}{|l|c|l|}
\hline \multicolumn{1}{|c|}{ Dimension } & Questions & \multicolumn{1}{c|}{ Concept } \\
\hline Generic & 1 to 12 & For general information \\
\hline Economic & 13 to 22 & Economic strength of the firm \\
\hline Social & 23 to 32 & The firm's social performance \\
\hline Ethics & 33 to 38 & Ethics code and transparent procedures \\
\hline Technology & 39 to 42 & Use of technology \\
\hline Environment & 43 to 46 & Environmentally friendly \\
\hline Innovation & 47 to 52 & Capacity of innovation \\
\hline
\end{tabular}

Source: Author's own, 2019. 
The questionnaire was based on known and already presented factors, but it also considered some important variables related to the ethics, social and environmental dimensions, these areas are increasingly taken into account for the valuation and qualification of companies (Materiality Map $S A S B, 2021)$.

Based on the information provided it was possible to identify a general idea on how a success factor model for the Fintech companies can be adopted to improve the welfare of the stakeholders. It is found several important correlations between the questions and three important indicators of the strength of the firm: i) Employee's growth rate, ii) Client's growth rate, iii) Age of the firm. ${ }^{4}$

\subsection{Construction of dimensions and indicators}

Since the key questions of the survey were answered in a Likert scale; the indicators were constructed counting the number of times that the respondents had an answer of "disagree" and "strongly disagree" or "agree" and "strongly agree" in each of the questions. Each question with a Likert scale implied a strength/weakness of the firm (see Appendix B). For example, the question: "Have you been able to reinvest utilities, since the start of the firm?" in this case, if the answer is "agree" or "strongly agree", that is taken to be a strength that might have contributed to its success.

For questions 13 to 52, it is added up all the number of responses related to the strength of the firm ("agree" plus "strongly agree") and then divided by the total number of responses, so that a percentage is obtained. Each radar chart corresponds to one dimension and the further away from the origin means a higher percentage of respondents that agree with that variable (question). Moreover, to compare the strengths in all the dimensions, it is created a combined radar chart plotting the average value of the total questions.

\section{Results}

In line with the presented literature, this study shows that the most important dimensions are the technological and ethical (regulatory and transparency) ones; respondents agree that these are relevant areas in their model; the innovation part referring to customer service and financial inclusion had also important relevance.

The first part of the survey shows some important statistical data that give a general outlook of how does the fintech industry in Mexico works, the firm's age and the main operation: the average initial year of operation is 2015, this makes sense because of the boom of the fintech sector in Mexico. According to the diverse types of fintech's operation, most of the firms have the payments and mobile money (transfers) services followed by crowdfunding and investments. For 2018, the number of employees they had in average is 21 , also the number of clients has increased in 89 percent between 2018 and 2019, which represents that firms have grown significantly. On average, their clients are legal entities, while 67 percent of them are located in an urban zone and 35 percent are women.

Regarding to the stipulated success indicators (employees' growth, client's growth and the age's firm) the most significative correlation they have with other variables are:

\footnotetext{
${ }^{4}$ There is a total of 15 firms that completed the survey.
} 
Table 2. Most significant correlations with success indicators

\begin{tabular}{|l|c|c|c|}
\hline \multicolumn{4}{|c|}{ Economics } \\
\hline \multicolumn{1}{|c|}{ Question } & GEmployees & Gclients & Age \\
\hline Q14 - Sales Growth & $0.6516^{*}$ & 0.3544 & -0.2417 \\
\hline Q21 - Idle Machinery & 0.0277 & 0.0076 & $-0.5973^{*}$ \\
\hline \multicolumn{3}{|c|}{ Social } \\
\hline Question & GEmployees & Gclients & Age \\
\hline Q27 - Competitive Wages & $0.5616^{*}$ & $0.5615^{*}$ & -0.1684 \\
\hline \multicolumn{3}{|c|}{ Innovation } \\
\hline Question & GEmployees & Gclients & Age \\
\hline Q52 - Public Funding for Innovation & 0.2450 & 0.4124 & $-0.6693^{*}$ \\
\hline
\end{tabular}

Source: Author's own from obtained data, 2019

Note: The correlations with asterisk are significant at the 5\% level.

The results are explained in the six dimensions of the questionnaire and all responses were classified to understand the strengths and weaknesses of these firms.

Figure 1 shows that the strongest dimension for the respondents fintech's is the technological, followed by the social and ethical. The economic and innovative factors are around 60 percent of strength and there is a weakness in the environmental dimension.

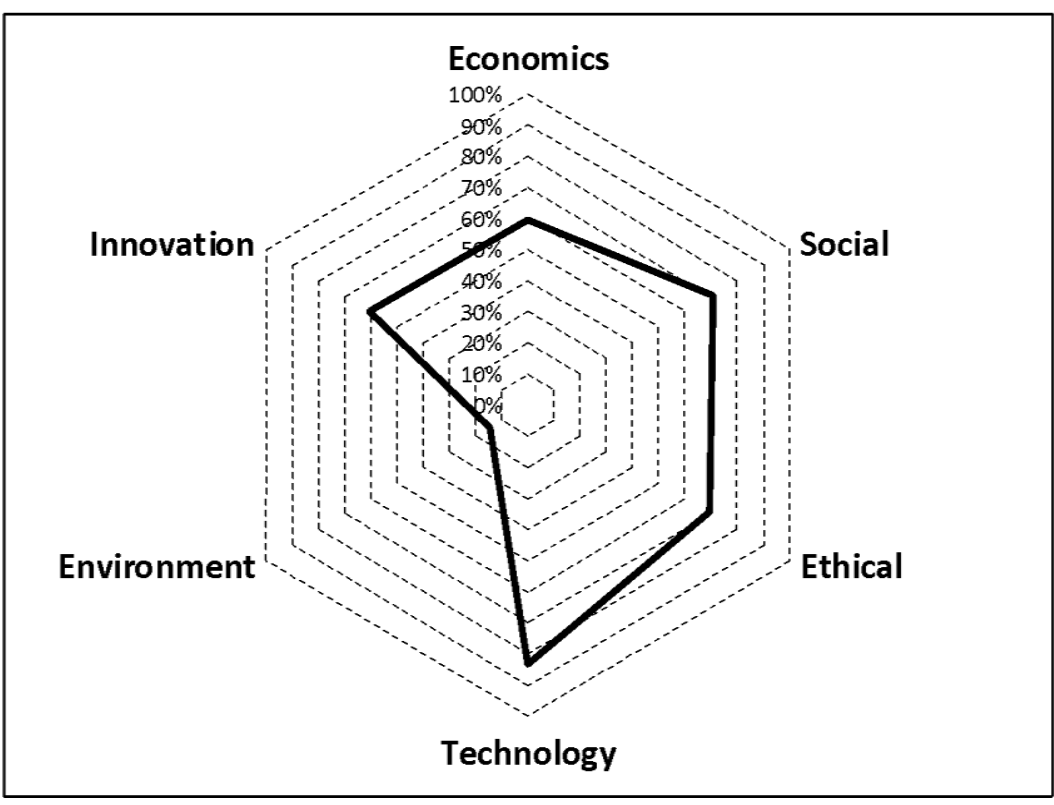

Figure 1. Results of all dimensions

Source: Author's own from questionnaire data, 2019. 


\subsection{Economic dimension}

Most respondents said they have been able to reinvest some profits since they started, but the majority had a visibly increasing in sales every year and a neutral reduce in operating costs, this means that the average of the firms has been growing and expanded their business.

Most of the companies have a high degree of leverage and has applied to external financing for their operations in a neutral manner, this means it has not been successful in obtaining external funding. All the companies have a suitable level of liquidity which means that the short-term transactions have no liquidity risk and can be faced without any difficulty and also, they do not have excess in machinery or equipment; moreover, 93 percent of respondents do not have idle machinery; which means that they are using machinery efficiently.

Only 40 percent of respondents' firms have income/expenditure balance. This might be a weakness since some of the firms are quite new and it might take a few years in the business to have an equilibrium.

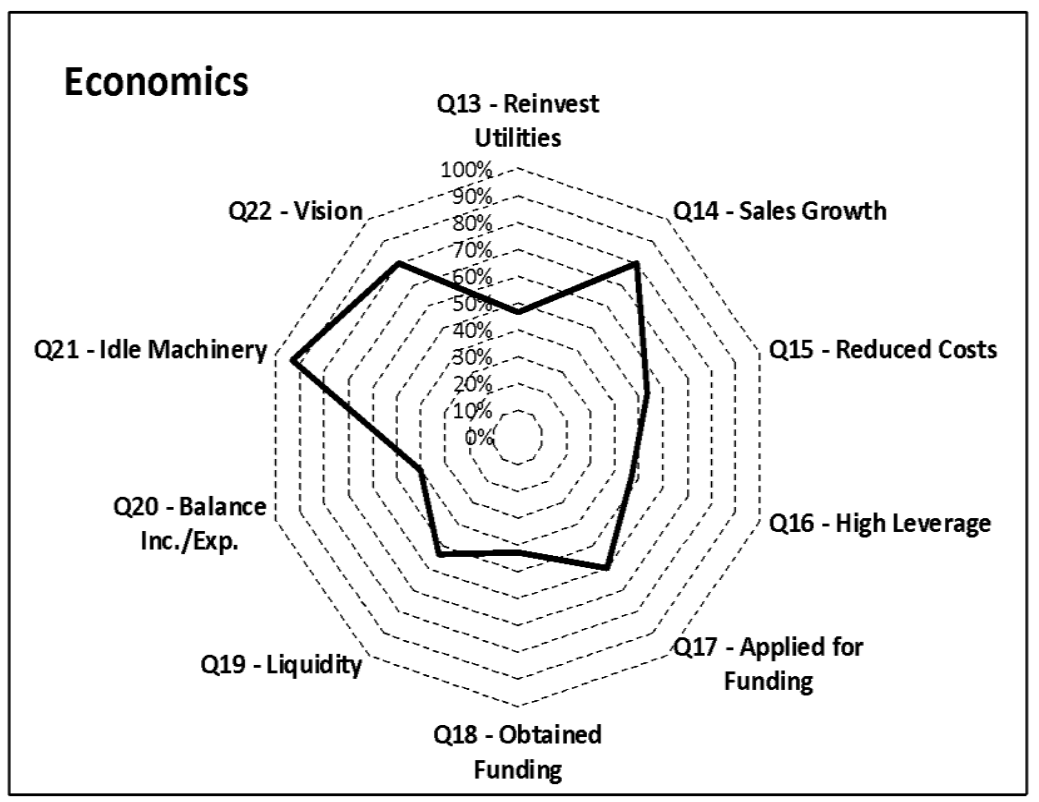

Figure 2. Results of economics dimension

Source: Author's own from questionnaire data, 2019.

\subsection{Social factor}

Most of the firms the company pay competitive salaries to the employees and offer better benefits than the governmental social securities, this is an incentive because it gives them the motivation to perform a good job so they can give a good service to the clients, additional most of the fintech respond that they give additional payments or benefits to those who achieve the established goals of its area or projects.

All fintech's measure the quality of service after-sales and have a consumer service department, before during and after the sale. Also, the firms manage with a high degree of 
operational flexibility, $98 \%$ of respondents have operational flexibility, this means that they adapt their operative processes to new products or clients easily. This is a strength because they are pioneers in their operation and have products and services that increase the financial inclusion that as we know, is one of the most important principles of the fintech industry.

The companies coincide that their facilities, equipment, and office furniture are appropriate for their operative functions and that they promote a safe and efficient working environment.

One point that stands out, is that many of the firms have not been involved in social projects, directly or through an organization, this represents an opportunity for them to roll out these activities especially because currently, the sustainability and environment is one of the core objectives for a successful company. Only 13 percent of them participate directly or support social projects, this is understandable in the sense that most of these firms are quite young and that implies that they might not have enough resources to devote to social projects. Moreover, since the regulation of this sector is not fully developed and no social norm is implemented, there is no legal necessity to have resources devoted to social projects.

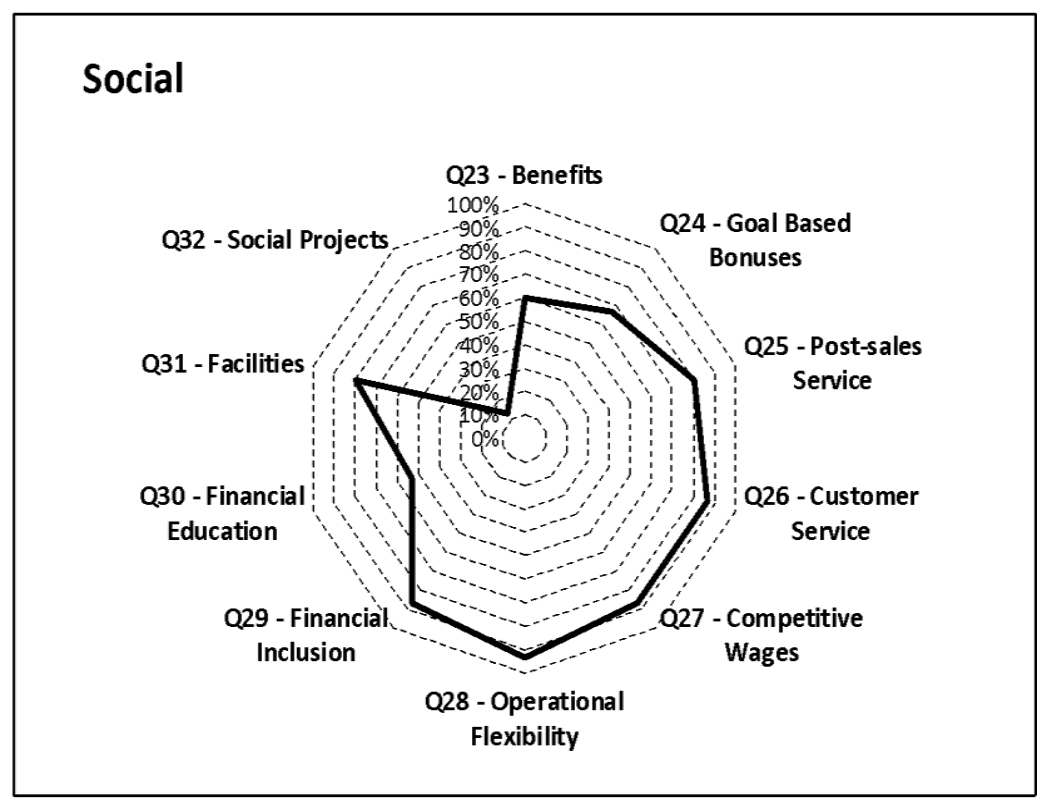

Figure 3. Results of social dimension

Source: Author's own from questionnaire data, 2019.

\subsection{Ethical dimension}

Organizations are constantly striving for a better ethical atmosphere within the business climate and culture, so we consider the ethical dimension plays a fundamental role and is essential that any kind of organizations, including the financial, consider this to it's continuity and growth. It is especially worrisome to think that only 67 percent of firms have an ethics code implemented where someone can review about the actions or behaviors in the firm; they have a department dedicated to the fulfillment of the law and the ethics code; however, about $30 \%$ do not have established one. 
One positive point in this dimension, is that all the firms present a report of annual or semiannual results to each of the stakeholders and inform them what have been the main activities they execute. Also, 87 percent of firms have a transparent information system; even though this seems to be quite high, it would be desirable to have the $100 \%$ in all the indicators of this dimension.

Half of the companies are registered (or in process) to the National Commission of Banking and Securities (CNBV), this is also important because above all, the firms must obey the rules that lay down the law.

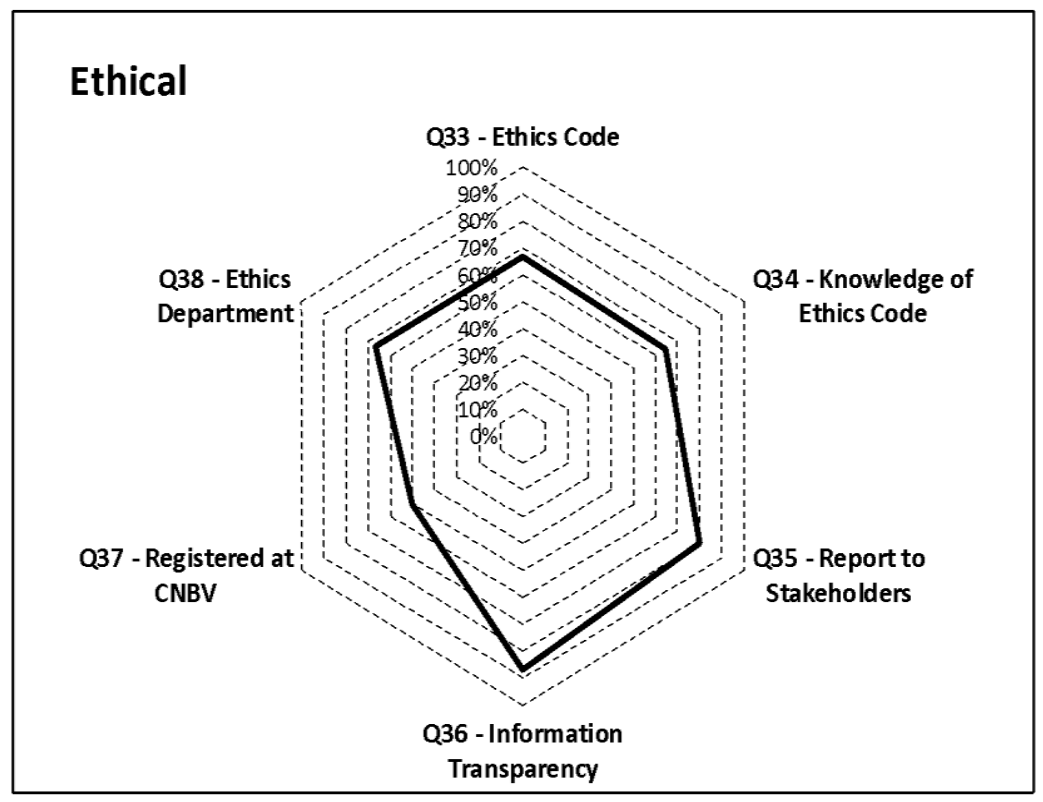

Figure 4. Results of ethical dimension

Source: Author's own from questionnaire data, 2019.

\subsection{Technological dimension}

This is a very important dimension for fintech industry, all of them have responded that have a special area of technical support and maintenance to their servers and equipment and most of them, about 85 percent have manuals available for assistance and use of the technological equipment and software.

Encryption is important because it allows firms to securely protect data and confidentiality; it is comforting that all the firms that responded to the survey use encryption technologies that allow the security of their transactions and information. In this area, 93 percent of respondents answered that they use encrypted technology for data and transaction safety.

Also, 73 percent have a technological tool or software for decision making such as dashboard or ERP (Enterprise Resource Planning), except one of them. 


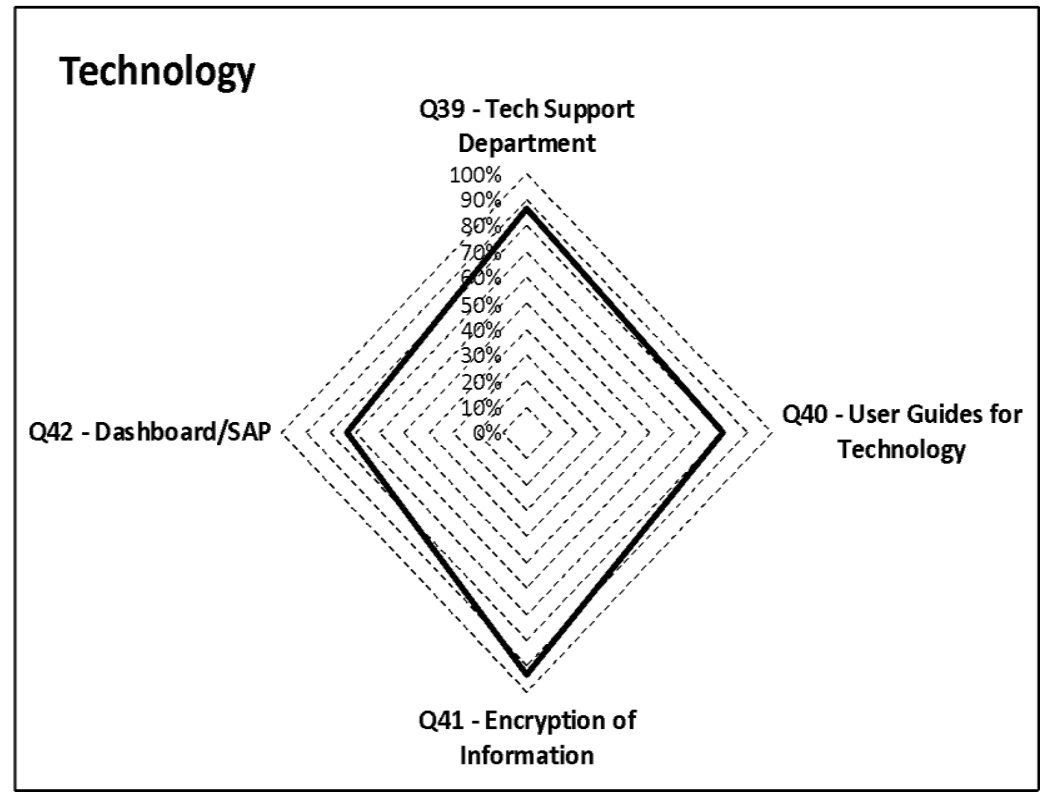

Figure 5. Results of technology dimension

Source: Author's own from questionnaire data, 2019.

\subsection{Environment dimension}

This dimension has the lowest scores of the entire survey; fintech firms clearly did not take into account this factor as an important one in these kinds of firms. Only 40 percent are working towards the reduction of the environmental impact; while none of them has someone trained in environmental issues in the firm, they do not care so much about training the employees in the field of environmental law enforcement, which represents an important opportunity to put in practice.

Few of the fintech have procedures and signage on the waste management and use some kind of renewable energy, about a 15 percent. 


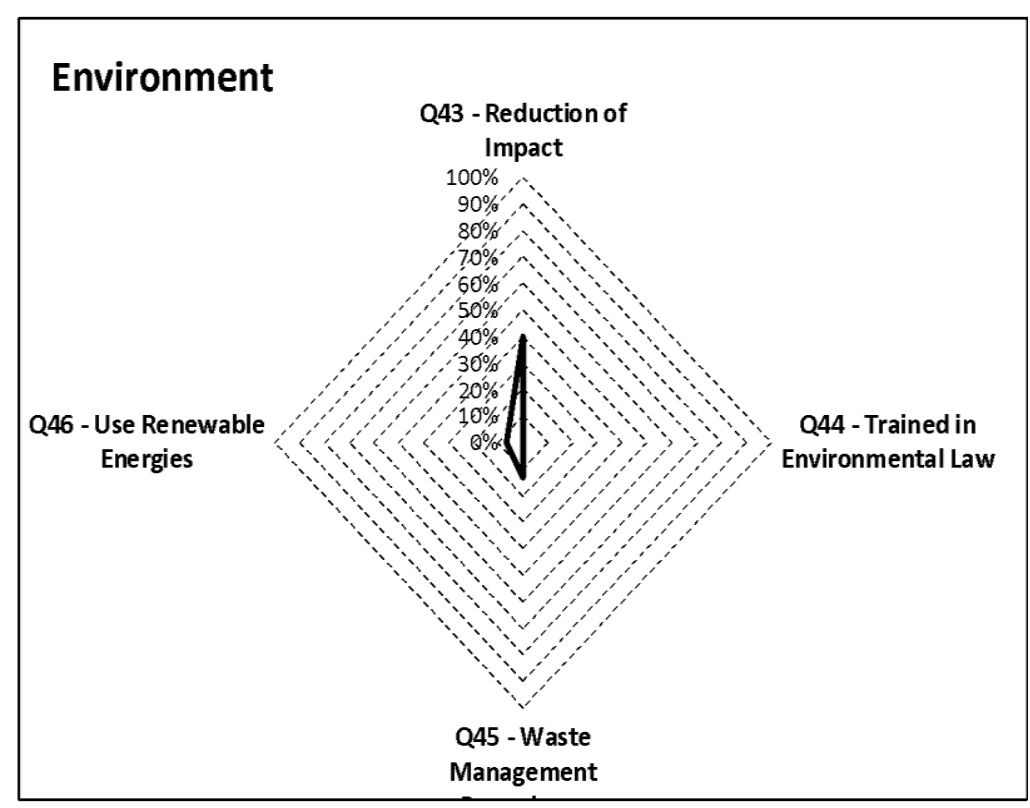

Figure 6. Results of environment dimension Source: Author's own from questionnaire data, 2019.

\subsection{Innovation factor}

For this factor, all the companies have developed new projects over the past year and most of them have had awards from official institutions. The financial product and service innovation is basic in the financial institutions, especially because it means implementing new ideas and creating dynamic products that make your business grow and be adapted to changes. It is no surprise that all the respondents answer that offer a unique financial service for their clients and their business model is innovative.

On the contrary to the above paragraph, only $33 \%$ of the firms has registered some patent of any of their innovative product or service and $20 \%$ has received public funding for innovation. There is a clear lack of resources devoted to innovation from the public sector, since only $20 \%$ of the firms were able to secure public funds for innovation. 


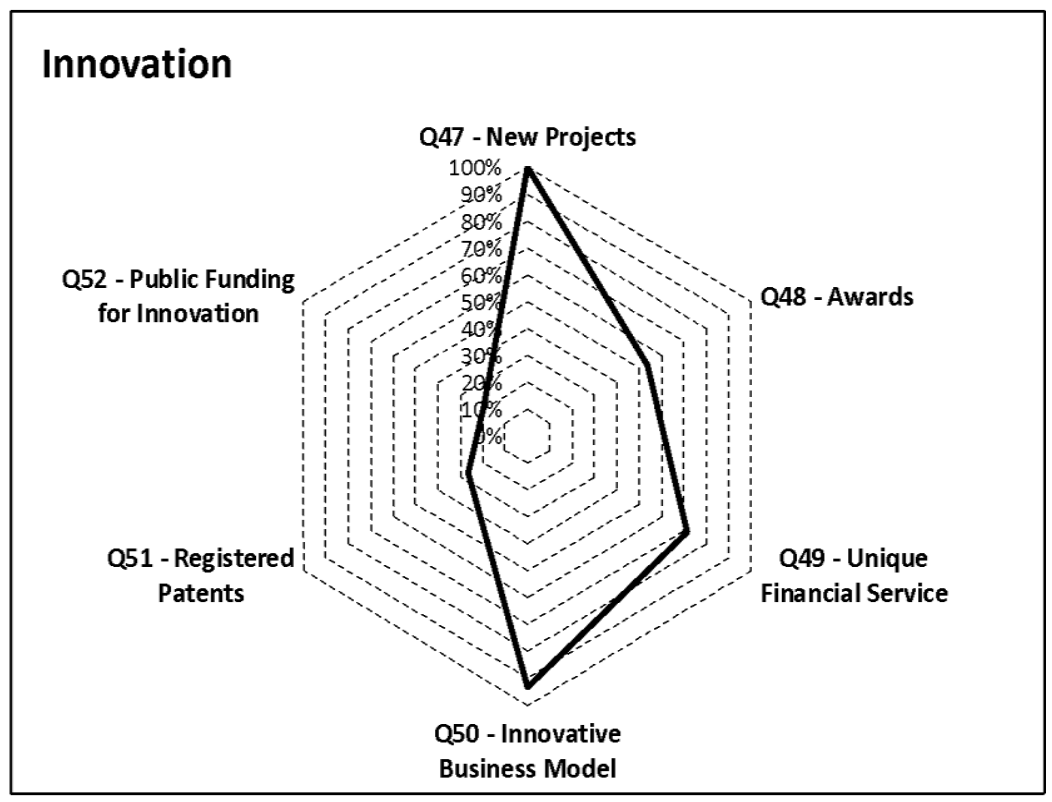

Figure 7. Results of innovation dimension

Source: Author's own from questionnaire data, 2019.

\section{Conclusions}

Most of the presented literature conclude that the most important success variables fintech's business model are "technology" (Q39, Q40), "regulation" (Q35, Q36), "information security" (Q41), "value proposition" (Q47, Q49, Q50) and "costumer's needs" (Q26, Q29); this coincide with this first and preliminary attempt to understand the industry in Mexico, couple with a new variable that is the "operational flexibility" (Q28).

Other notable success variables are the efficient use of machinery and physical infrastructure, the post-sales service, competitive wages, and new products development that all together come with the financial inclusion. A current deficiency for the firms is the economic dimension, most of them have not been able to reinvest profits and reduce their operational costs, they have a low liquidity and a minimum funding support.

Despite that the environmental dimension has low relevance or application for Fintech's, I consider that for long-term growth and added value, it will be increasingly important in the industry worldwide, even more with the SDGs and sustainable reporting standards. There is a large and interesting research field to continue with more related studies for a better understanding of the sector in Mexico.

There will be new opportunities for the fintech industry after the COVID-19 pandemic, they must pay attention to create alliances with financial institutions and organizations so they can adapt and innovate new products and digital solutions contributing to the advancing financial inclusion programs. For an appropriate knowledge of the industry in Mexico, it is important to constitute more associations and hubs relating that inform in an efficient way the activities and projects of the members. 


\section{References}

[1] Arner, D. W., Buckley, R. P., Zetzsche, D. A., \& Veidt, R. (2020). Sustainability, FinTech and Financial Inclusion. European Business Organization Law Review, 21(1). https://doi.org/10.1007/s40804-02000183-y

[2] Arouche, P., \& Balaj, B. (2020). FinTech, an Emerging Industry-An Explorative Study of Business Model Innovation on FinTech Companies in Sweden [SödertörnUniversity]. https://www.divaportal.org/smash/get/diva2:1442301/FULLTEXT01.pdf

[3] Bancomext. (2018a). FINTECH EN EL MUNDOLA REVOLUCIÓN DIGITAL DE LAS FINANZAS HA LLEGADO A MÉXICO.

[4] Bancomext, P. (2018b). MÉXICO: NACIÓN FINTECH. Nuevos negocios y ecosistemas en el sector financiero mexicano. https://www.bancomext.com/wp-content/uploads/2018/12/MEXICONACION-FINTECH-V5.pdf

[5] Bjorkegren, D., \& Grissen, D. (2018). Behavior Revealed in Mobile Phone Usage Predicts Loan Repayment. SSRN Electronic Journal. https://doi.org/10.2139/ssrn.2611775

[6] Ley para regular las instituciones de tecnología financiera, Pub. L. No. Nueva Ley D0F 09-03-2018, http://www.diputados.gob.mx/LeyesBiblio/pdf/LRITF_090318.pdf http://www.diputados.gob.mx/LeyesBiblio/pdf/LRITF_090318.pdf

[7] Deloitte. (2020). Fintech | On the brink of further disruption. https://www2.deloitte.com/content/dam/Deloitte/nl/Documents/financial-services/deloitte-nl-fsifintech-report-1.pdf

[8] Demirguc-Kunt, A., Klapper, L., Singer, D., Ansar, S., \& Hess, J. (2018). The Global Findex Database 2017: Measuring Financial Inclusion and the Fintech Revolution. In The Global Findex Database 2017: Measuring Financial Inclusion and the Fintech Revolution. Washington, DC: World Bank. https://doi.org/10.1596/978-1-4648-1259-0

[9] Eickhoff, M., Muntermann, J., \& Weinrich, T. (2017). What do FinTechs actually do? A Taxonomy of FinTech Business Models. 38th International Conference on Information Systems. ICIS Proceeding.

[10] Fernández De Lis, S., \& Ortún, P. U. (2018). Digital transformation and competition in the financial sector.

[11] Findexable. (2019). The Global Fintech Index 2020. The Global Fintech Index City Ranking Report. https://findexable.com/wp-content/uploads/2019/12/Findexable_Global-Fintech-Rankings2020exSFA.pdf

[12] Fintech Radar Mexico. (2020). Finnovista. Https://Www.Finnovista.Com/En/Radar/the-Number-ofFintech-Startups-in-Mexico-Grows-14-in-One-Year-to-441/.

[13] Francis, E., Blumenstock, J., \& Robinson, J. (2017). Digital Credit: A Snapshot of the Current Landscape and Open Research Questions. https://people.ucsc.edu/ jmrtwo/digital_credit_landscape.pdf

[14] Gozman, D., Liebenau, J., \& Mangan, J. (2018). The Innovation Mechanisms of Fintech Start-Ups: Insights from SWIFT's Innotribe Competition. Journal of Management Information Systems, 35(1). https://doi.org/10.1080/07421222.2018.1440768

[15] Hills, G. E., \& Laforge, R. W. (1992). Research at the Marketing Interface to Advance Entrepreneurship Theory. Entrepreneurship Theory and Practice, 16(3). https://doi.org/10.1177/104225879201600303

[16] Lee, I., \& Shin, Y. J. (2018). Fintech: Ecosystem, business models, investment decisions, and challenges. Business Horizons, 61(1), 35-46. https://doi.org/10.1016/j.bushor.2017.09.003

[17] Materiality Map - SASB. (2021). Sustainability Accounting Standards Board . https://www.sasb.org/standards/materiality-map/ 
[18] Park, J.-K., Lee, H.-S., Kim, S.-J., \& Park, J.-P. (2015). A Study on Secure Authentication System using Integrated User Authentication Service. Indian Journal of Science and Technology, 8(23). https://doi.org/10.17485/ijst/2015/v8i23/79284

[19] Quesada, V. (2017). When Tech Meets Finance: A Roadmap for Digital Banking Transformation.

[20] Roeder, J., Rodríguez Cardona, D., Palmer, M., Werth, O., Muntermann, J., \& Breitner, M. H. (2018). Make or Break: Business Model Determinants of FinTechVenture Success. https://www.researchgate.net/profile/Oliver-

Werth/publication/327230868_Make_or_Break_Business_Model_Determinants_of_FinTech_Venture_ Success/links/5cac528a92851c64bd59f54c/Make-or-Break-Business-Model-Determinants-ofFinTech-Venture-Success.pdf

[21] Secretaría de Hacienda y Crédito Público. (2018). El sector Fintech y su regulación en México. Https://Www.Gob.Mx/Shcp/Articulos/El-Sector-Fintech-y-Su-Regulacion-En-Mexico?Idiom=es. https://www.gob.mx/shcp/articulos/el-sector-fintech-y-su-regulacion-en-mexico?idiom=es

[22] Shin, Y. J., \& Choi, Y. (2019). Feasibility of the Fintech Industry as an Innovation Platform for Sustainable Economic Growth in Korea. Sustainability, 11(19). https://doi.org/10.3390/su11195351

[23] Zbinden, F., \& Kondova, G. (2019). Economic Development in Mexico and the Role of Blockchain. Advances in Economics and Business, 7(1). https://doi.org/10.13189/aeb.2019.070106 